\title{
DESAIN PEMBANGKIT LISRIK DENGAN MEMANFAATKAN PUTARAN MESIN KE RODA BELAKANG SEPEDA MOTOR
}

\author{
Indra Umarella \\ Teknik Mesin, Fakultas Teknik \\ Universitas Maarif Hasyim Latif, Sidoarjo, Indonesia \\ e-mail : indra-umarella@student.umaha.ac.id
}

\begin{abstract}
ABSTRAK
Energi listrik bagi manusia adalah energi yang berperan penting bagi kehidupan kegiatan pada industri dan kegiatan rumah tangga adalah contohnya akan tetapi tarif yang dikeluarkan untuk dapat menikmatinya terlampau cukup mahal maka diperlukan alternatif untuk dapat meringankan beban konsumsi energi listrik untuk kehidupan sehari-hari Terdapat beberapa cara untuk menekan anggaran lisrik rumah tangga yang mahal salah satunya adalah dengan membuat pembangkit listrik sederhana dengan tujuan untuk mengurang ketergantungan terhadap energi listrik dari PLN. Salah satu energi alternatif yang dapat digunakan adalah energi gerak dari mesin motor yang digunakan untuk menggerakkan roda belakang sepeda motor (garak putar rantai) untuk menggerakkan generator. Maksud dari penelitian ini ialah dapat membuat prototipe pembangkit listrik dengan memanfaatkan energi putar rantai sepeda motor serta dapat mengetahui daya yang dihasilkan oleh pembangkit listrik tersebut dan dapat pula mengetahui lamanya waktu pengisian yang dibutuhkan untuk mengisi batarai 12 volt dengan kapasitas $5 \mathrm{Ah}$ (Ampere hour). Pengujian dan pengambilan data pada alat pembangkit listrik ini dilakukan selama 75 menit pada kecepatan kendaraan 40,50, 60,70 Km/Jam adapun daya rata-rata yang dapat pada kecepatan $40 \mathrm{Km} / \mathrm{Jam}$ adalah $0,788 \mathrm{~W}$ pada kecepatan $50 \mathrm{Km} / J a m$ daya rata-rata yang dihasilkan adalah 3,346 W pada kecepatan $60 \mathrm{Km} / J a m$ daya rata-rata yang dihasilkan adalah 6,487 W pada kecepatan 70 $\mathrm{Km} / \mathrm{Jam}$ daya rata-rata yang dihasilkan adalah 9,903 W berdasarkan pengujan selama 75 menit maka perkiraan waktu pengecasan pada kecepatan $40 \mathrm{Km} / \mathrm{Jam}$ adalah 83,33 jam pada kecepatan $50 \mathrm{Km} / \mathrm{Jam}$ adalah 25 jam pada kecepatan $60 \mathrm{Km} / \mathrm{Jam}$ adalah 9,25 jam pada kecepatan $70 \mathrm{Km} / \mathrm{Jam}$ adalah 5,76 jam.
\end{abstract}

Keywords : Energi alternatif, Energi listrik, Generator, Gerak putar rantai, Pembangkit listrik.

\section{PENDAHULUAN}

\subsection{Latar belakang}

Energi listrik bagi manusia adalah energi yang berperan penting bagi kehidupan kegiatan pada industri dan kegiatan rumah tangga adalah contohnya energi lisrik pada industri digunakan sebagai penerangan dan juga untuk proses produksi yang menggunakanenergi listrik sebagai sumber energi utama, sedangkan untuk kegiatan rumah tanggan digunakan untuk penerangan dan untuk menghidupkan barang-barang elektonik seperti : televisi, setrika, handphone dll. Melihat begitu pentingnya manfaat energi lisrtik untuk kehidupan sehari-hari umat manusia sedangkan tarif yang di keluarkan untuk dapat menikmatinya terlampau mahal (khususnya untuk kegiatan rumah tangga) dengan adanya penyesuaian tdl (tarif dasar listik) dan juga dengan adanya pencabutan subsidi bagi golongan $900 \mathrm{va}$ (vold ampere) yang masuk dalam kategori rumah tangga mampu semakin membebani keuangan hanya untuk mebayar listri. Untuk itu maka diperlukan alternatif lain untuk meringankan beban konsumsi energi listrik untuk kehidupan sehari-hari.
Terdapat beberapa cara untuk menekan anggaran lisrik rumah tangga yang mahal salah satunya adalah dengan membuat pembangkit listrik sederhana dengan tujuan agar masyarakat tidak terlalu bergantung dengan listrik dari pln. Salah satu alternatif yang dapat digunakan adalah energi gerak dari mesin motor yang digunakan untuk menggerakkan roda belakang sepeda motor.

Selama ini putaran mesin pada sepeda motor hanya digunakan untuk menggerakkan roda saja tetapi putaran mesin tersebut juga dapat kita manfaatkan sebagai penghasil energi listrik dengan cara meletakan gigi yang telah di sambungkan pada dinamo ampere (alternator/generator) ke rantai yang menghubungkan antara mesin dengan roda belakang, lalu energi listrik dihasikan oleh generator dialirkan ke batrai untuk disimpan energi listrik yang berada didalam baterai dapat digunakan untuk peralatan elektronik dengan arus lisrik dc (direct current) salah satu contohnya adalah mencharger hp / laptop ataupun arus ac (alternating current), untuk arus listrik mengunakan alat pengubah arus dc ke ac (inverter).

berdasarkan latar belakang yang telah disebutkan tadi menunjukan bahwa penulis akan meneliti tentang pemanfaatan gerak putar mesin sepeda motor untuk 
menghasilkan energi listrik tegangan rendah sehingga dapat sedikit mengurang pemakaian listrik dari pln selain itu juga dapat mempermudah aktivitas mahasiswa karena tidak perlu lagi mencarge handphone atau laptop terlebih dahulu sebelum beraktivitas.

\subsection{Rumusan masalah}

Berdasarkan latar belakang tersebut dapat dirumuskan permasalahan sebagai berikut:

1. Bagaimana merancang alat pembangkit listrik dengan memanfaatkan gerak putar mesin ke roda belakang sepeda motor.

2. Mengetahui berapa besar daya yang dapat dihasilkan dari pembangkit listrik tersebut.

3. Mengetahui lamanya waktu pengisian pada batrai 12v dengan dengan kapasitas 5 ah (ampere hour)

\subsection{Tujuan}

Adapun tujuan dari penulisan ini adalah sebagai berikut

1. Dapat membuat prototipe pembangkit listrik dengan memanfaatkan energi gerak putar mesin ke roda belakang sepeda motor

2. Dapat mengetahui daya yang dihasilkan oleh pembangkit listrik tersebut.

3. Dapat mengetahui lamanya waktu yang diperlukan untuk mengisi batarai $12 \mathrm{v}$ dengan kapasitas 5 ah (ampere hour)

\subsection{Batasan Masalah}

Untuk mempermudah penulis dalam melakukan penelitian pada pembangkit lisrtik sederhana dengan memnfaatkan putaran mesin sepeda motor maka diperlukan batasan masalah antara lain :

1. Kecepatan maksimum kendaraan adalah $70 \mathrm{~km} / \mathrm{jam}$.

2. Kecepatan kendaraan yang diteliti adalah $10,20,30$, 40, 50, 60, dan $70 \mathrm{~km} / \mathrm{jam}$.

3. Batrai yang digunakan adalah accu denagn kapasitas 5 ah (ampere hour).

4. Generator yang digunakan adalah dinamo dc 24 volt.

5. Hanya meneliti pengecasan pada batrai.

\section{METODE PENELITIAN}

1. Studi Literatur

Studi literatur diperlukan supaya penulis dapat menambah pengetahuan seta wawasan pada materi yang berkaiatan dengan penelitian tugas akhir ini. Studi literatur yang dilakukan penulis ialah mengkajian dan mengambil sejumlah teori yang menunjang pada tugas akhir terdahulu, buku-buku, jurnal ilmiah, serta artikel yang berhubungan dengan penelitian ini. penulis berharap agar hasil dari studi literatur dapat menjadi acuan dalam menganalisa hasil dari pengujian yang dilakukan.

2. Identifikasi Masalah

Kegiatan yang akan di lakukan dalam pengidentifikasian masalah dalam kegiatan penelitian ini adalah mengetahui kinerja dari mekanisme kerja dari pembangkit listrik tenaga mesin sepeda motor.

3. Perancangan Mekanisme

Dalam perancangan ini dibuat suatu mekanisme penghasil energi listrik dengan menggunakan prinsip gaya gerak listrik (GGL) yang berbentuk roda yang ditaruh di atas rantai sepeda motor. Prinsip kerja dari mekanisme ini adalah dengan memanfaatkan energi gerak mesin sepeda motor dimana dengan putaran mesin tersebut diubah oleh dinamo ampere (Alternator) dan dapat menghasilkan energi listrik.

4. Pengujian mekanisme pembangkit listrik Pada proses pengujian ini dilakukan untuk memastikan apakah generator dapat menghasikan energi listrik jika alat pembangkit tidak menghasilkan listrik maka perlu perbaikanulang hingga dapat menghasilkan listrik sesuai danagn yang diingimkan.

5. Pengambilan data

Dalam pengambilan data dilakukan sebanyak beberapa kali sehingga didapatkan hasil yang paling baik barulah data tersebut dapat diolah.

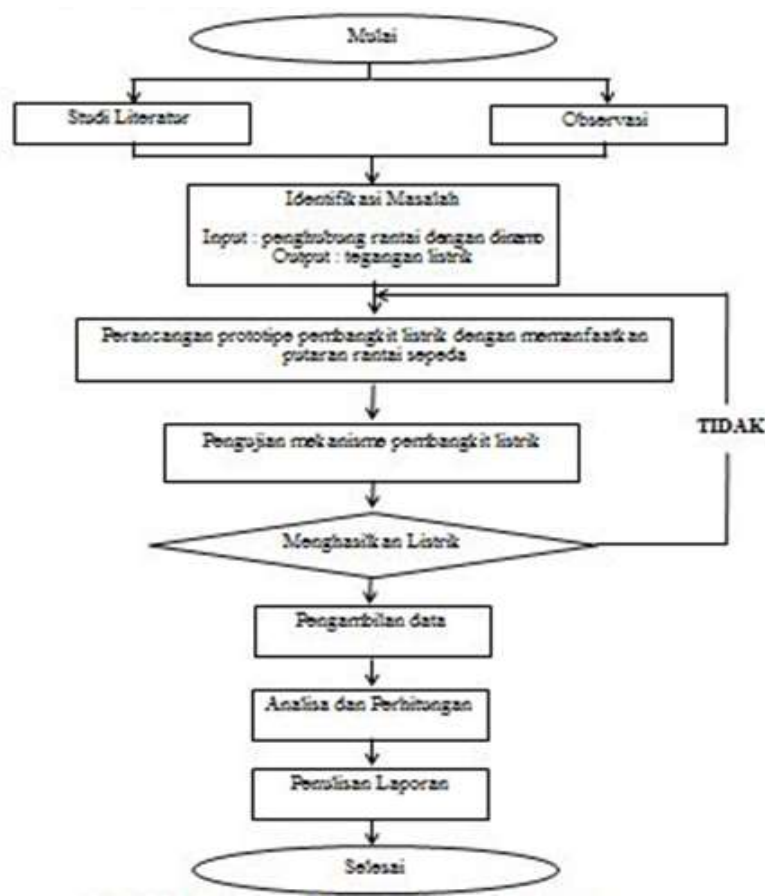

Gambar 1 : Diagram alur proses pengerjaan (flow chart)

\section{HASIL DAN PEMBAHASAN}

\section{Penulisan Persamaan Matematika}

Tinggi rendahnya kecepatan putar rotor selama waktu tertentu mempengaruhi tegangan yang di hasilkan oleh generator. bila generator dibebankan dengan beban tinggi dan kecepatan RPM yang konstan maka mengakibatkan tegangan generator akan turun akibat drop tegangan. Seperti pada hukum Faraday tinggi rendahnya tegangan yang dihasilkan dipengaruhi oleh banyaknya lilitan dan kecepatan putar rotor yang 
mempengaruhi pergantian fluks magnetik tiap satuan waktu. Semakin panjang kawat dan semakin kecil luas penampang atau diameter kawat maka hambatan (R) semakin tinggi begitu pula sebaliknya. Semakin besar hambatan (R) semakin kecil arus yang mengalir dan sebaliknya. Hal ini dapat dilihat pada persamaan hukum Ohm.

Dimana :

$$
I=\frac{V}{R}
$$

$\mathrm{I}=$ arus (Ampere)

$\mathrm{V}=$ tegangan $($ Volt $)$

$\mathrm{R}=$ hambatan $(\mathrm{Ohm}$

Berdasarkan percobaan yang telah dilakukan seperti pada percobaan ke 3 dimana generator dipasang denagan akumulator sehinggan dapat menghasilkan arus listrik dalam satuan (ampere) maka dapat diketahui daya yang dapat dihasilkan oleh generator, untuk mengetahui daya diperlukan rumus sebagai berikut:

Dimana :

$$
P=V . \text { I Atau } P=I^{2} \cdot R \text { Atau } P=V^{2} / R
$$

$\mathrm{P}=$ Daya Listrik (Watt)

$\mathrm{V}=$ Tegangan $($ Volt $)$

$\mathrm{I}=$ Arus (Ampere)

$\mathrm{R}=$ Hambatan $(\mathrm{ohm})$

1. Dengan kecepatan konstan $40 \mathrm{KM} / \mathrm{JAM}$

a) $\mathrm{P}=\mathrm{V}$. I

= 11,16.0,09

$=1,004$ Watt

b) $\mathrm{P}=\mathrm{V}$. I

$=11,26 \cdot 0,09$

$=1,013 \mathrm{Watt}$

c) $\mathrm{P}=\mathrm{V}$. I

$=11,29 \cdot 0,09$

$=1,016 \mathrm{Watt}$

d) $\mathrm{P}=\mathrm{V}$. I

$=11,33 \cdot 0,05$

$=0,566 \mathrm{Watt}$

e) $\mathrm{P}=\mathrm{V}$. I

$=11,36 \cdot 0,03$

$=0,340$ Watt

2 Dengan kecepatan konstan $50 \mathrm{KM} / \mathrm{JAM}$

a) $\mathrm{P}=\mathrm{V}$. I

$=11,22 \cdot 0,35$

$=3,927 \mathrm{Watt}$

b) $\mathrm{P}=\mathrm{V}$. I

$=11,28 \cdot 0,28$

$=3,158$ Watt

1. Adapun lama wktu pengisian berdasarka data tabel percobaan pengecasan maka diperoleh perhitungan sebagai berikut:1. Pada saat kecepatan kendaraan 40 KM/JAM, dan kecepatan rotasi pada rotor 1037 RPM arus yang mengalir adalah 0,06 Ampere, untuk memenuhi akumulator dengan kapasitas 5Ah maka waktu yang didutuhkan untuk pengecasan adalah

$$
T=\frac{\text { Kapasitas Batrai }}{I}
$$

c) $\mathrm{P}=\mathrm{V}$.I

$=11,34 \cdot 0,26$

$=3,288 \mathrm{Watt}$

d) $\mathrm{P}=\mathrm{V} . \mathrm{I}$

$=11,39 \cdot 0,29$

$=3,303$ Watt

e) $\mathrm{P}=\mathrm{V}$. I

$=11,42 \cdot 0,20$

$=2,284$ Watt

3. Dengan kecepatan konstan $60 \mathrm{KM} / \mathrm{JAM}$

a) $\mathrm{P}=\mathrm{V} . \mathrm{I}$

$=11,24 \cdot 0,59$

$=6,631 \mathrm{Watt}$

b) $\mathrm{P}=\mathrm{V} . \mathrm{I}$

$=11,29 \cdot 0,56$

$=6,322 \mathrm{Watt}$

c) $\mathrm{P}=\mathrm{V} . \mathrm{I}$

$=11,38 \cdot 0,57$

$=6,486$ Watt

d) $\mathrm{P}=\mathrm{V}$. I

$=11,42 \cdot 0,57$

$=6,509 \mathrm{Watt}$

e) $\mathrm{P}=\mathrm{V} . \mathrm{I}$

$=11,50 \cdot 0,56$

$=6,486$ Watt

4. Dengan kecepatan konstan $70 \mathrm{KM} / \mathrm{JAM}$

a) $\mathrm{P}=\mathrm{V} . \mathrm{I}$

$=11,29 \cdot 0,87$

$=9,822$ Watt

b) $\mathrm{P}=\mathrm{V} . \mathrm{I}$

$=11,39 \cdot 0,81$

$=9,822$ Watt

c) $\mathrm{P}=\mathrm{V} . \mathrm{I}$

$=11,48 \cdot 0,87$

$=9,988$ Watt

d) $\mathrm{P}=\mathrm{V}$.I

$=11,52 \cdot 0,87$

$=10,022 \mathrm{Watt}$

e) $\mathrm{P}=\mathrm{V}$.I

$=11,60 \cdot 0,85$

$=9,860$ Watt

Berdasarkan data yang telah diambil maka perkiraan lamanya waktu pengisian arus ke akumulator yang berkapasitas 5Ah dapat dihitung dengan rumus

$$
T=\frac{\text { kapasitas batrai }(A h)}{I}
$$

Dimana :

$\mathrm{T}=$ Waktu pengisian (Jam)

$\mathrm{I}=$ Arus yang mengalir (Ampere)

$$
\begin{aligned}
& =\frac{5 A h}{0,06 \mathrm{~A}} \\
& =83,33 \mathrm{jam}
\end{aligned}
$$

2. Pada saat kecepatan kendaraan $50 \mathrm{KM} / \mathrm{JAM}$, dan kecepatan rotasi pada rotor 548,5 RPM arus yang mengalir adalah 0,13 Ampere untuk memenuhi akumulator dengan kapasitas 5Ah maka waktu yang didutuhkan untuk pengecasan adalah

$$
T=\frac{\text { Kapasitas Batrai }}{I}
$$




$$
\begin{array}{r}
=\frac{5 \mathrm{Ah}}{0,2 \mathrm{~A}} \\
=25 \mathrm{jam}
\end{array}
$$

3. Pada saat kecepatan kendaraan $40 \mathrm{KM} / \mathrm{JAM}$, dan kecepatan rotasi pada rotor 1240 RPM arus yang mengalir adalah 0,23 Ampere untuk memenuhi akumulator dengan kapasitas 5Ah maka waktu yang didutuhkan untuk pengecasan adalah

$$
\begin{aligned}
T & =\frac{\text { Kapasitas Batrai }}{I} \\
& =\frac{5 \mathrm{Ah}}{0,54 \mathrm{~A}} \\
= & 9,25 \mathrm{jam}
\end{aligned}
$$

4. Pada saat kecepatan kendaraan $40 \mathrm{KM} / \mathrm{JAM}$, dan kecepatan rotasi pada rotor 1521 RPM arus yang mengalir adalah 0,66 Ampere untuk memenuhi akumulator dengan kapasitas 5Ah maka waktu yang

\begin{tabular}{|c|c|c|c|c|}
\hline \multirow{2}{*}{$\begin{array}{l}\mathrm{N} \\
\mathrm{O}\end{array}$} & \multirow{2}{*}{$\begin{array}{c}\text { Kecepatan } \\
\text { Kendaraa } \\
n \\
\text { (KM/JAM) }\end{array}$} & \multirow{2}{*}{$\begin{array}{l}\text { Kecepata } \\
\text { n Putar } \\
\text { (RPM) }\end{array}$} & \multicolumn{2}{|c|}{$\begin{array}{c}\text { Tegangan Output } \\
\text { Sebelum } \\
\text { Dipasang Accu }\end{array}$} \\
\hline & & & $\begin{array}{l}\text { Output } \\
\text { VAC } \\
\text { (Volt) }\end{array}$ & $\begin{array}{l}\text { Outpu } \\
\text { t VDC } \\
\text { (Volt) }\end{array}$ \\
\hline 1 & 10 & 36,9 & 6,2 & 3,3 \\
\hline 2 & 20 & 548,5 & 13,3 & 6,4 \\
\hline 3 & 30 & 783,7 & 18,9 & 7,6 \\
\hline 4 & 40 & 1037 & 25,2 & 12 \\
\hline 5 & 50 & 1240 & 28,8 & 13,7 \\
\hline 6 & 60 & 1328 & 33,7 & 15,4 \\
\hline 7 & 70 & 1521 & 42,2 & 17,5 \\
\hline
\end{tabular}
didutuhkan untuk pengecasan adalah

$$
\begin{gathered}
T=\frac{\text { Kapasitas Batrai }}{I} \\
=\frac{5 \mathrm{Ah}}{0,87 \mathrm{~A}} \\
=5,76 \mathrm{jam}
\end{gathered}
$$

Tabel 1. Perubahan Kecepatan Rotasi Pada Rotor Sebelum Dipasang Accu

Percobaan pertama yang dilakukan adalah mengukura tegangan yang didapatkan pada waktu belum terbebani atau terpasang akumulator terhadap perubahan kecepatan rotasi rotor di dalam RpM.

Keluaran VDC adalah tegangan yang keluar searah dikarenakan telah disearahkan dengan rectifier (dioda bridge ). Belum ada arus yang mengalir karena masih belum dipasang beban akumulator.

Berdasarkan Gambar 2. menunjukkan bahwa pada saat kecepatan putar rotor 367,9 RPM menghasilkan keluaran tegangan AC sebesar 6,2 Volt dan keluaran tegangan DC sebesar 3,3 Volt. Pada saat kecepatan putar rotor 548,6 menghasilkan keluaran tegangan AC sebesar 13,3 Volt dan keluaran tegangan DC sebesar 6,4 Volt. Pada saat kecepatan putar rotor 783,7 RPM menghasilkan keluaran tegangan AC sebesar 18,9 Volt dan keluaran tegangan DC sebesar 7,6 Volt. Pada saat kecepatan putar rotor 1037 RPM menghasilkan keluaran teganagn AC sebesar 25,2 Volt dan keluaran tegangan DC sebesar 12 Volt. Pada saat kecepatan putar rotor 1240 RPM menghasilkan keluaran tegangan AC sebesar 28,8 Volt dan keluaran tegangan DC sebesar 13,7 Volt. Dan pada saat kecepatan putar rotor 1328 RPM menghasilkan keluaran tegangan AC sebesar 33,7 Volt dan output tegangan DC sebesar 15,4 Volt dan pada saat kecepatan putar rotor 1521 menghasilkan keluaran tegangan AC sebesar 42,2 Volt dan Output DC sebesar 17,5 Volt

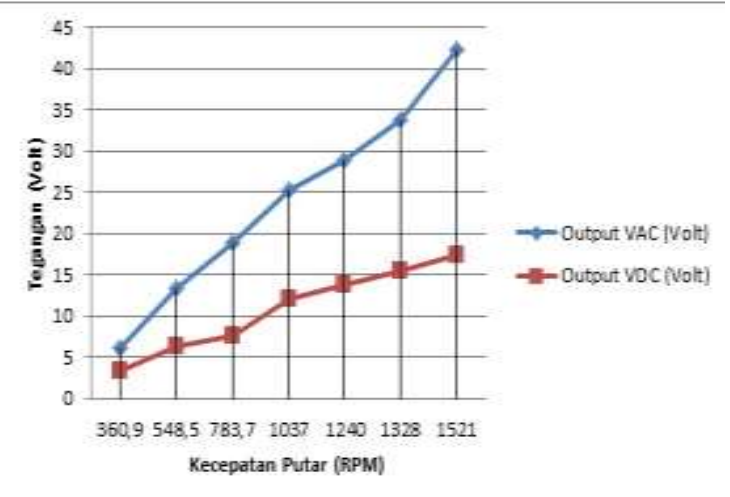

Gambar 1. Perubahan Kecepatan Rotasi Pada Rotor

Dari penjelasan diatas dapat disimpulkan bahwa semakin tinggi putaran rotor (RPM) semakin tinggi pula output tegagan (Volt) yang dihasilkan sesuai dengan hukum farady, output tegangan DC adalah tegangan yang

\begin{tabular}{|c|c|c|c|c|}
\hline \multirow{2}{*}{$\begin{array}{l}\mathrm{N} \\
\mathrm{O}\end{array}$} & \multirow{2}{*}{$\begin{array}{c}\text { Kecepatan } \\
\text { Kendaraa } \\
n \\
\text { (KM/JAM) }\end{array}$} & \multirow{2}{*}{$\begin{array}{c}\text { Kecepata } \\
\text { n Putar } \\
(\mathrm{RPM})\end{array}$} & \multicolumn{2}{|c|}{$\begin{array}{c}\text { Tegangan } \\
\text { Output Setelah } \\
\text { Dipasang Accu }\end{array}$} \\
\hline & & & $\begin{array}{l}\text { Output } \\
\text { VAC } \\
\text { (Volt) }\end{array}$ & $\begin{array}{l}\text { Outpu } \\
\text { t VDC } \\
\text { (Volt) }\end{array}$ \\
\hline 1 & 10 & 36,9 & 6 & 12 \\
\hline 2 & 20 & 548,5 & 13,8 & 12 \\
\hline 3 & 30 & 783,7 & 21,5 & 12 \\
\hline 4 & 40 & 1037 & 24,9 & 12 \\
\hline 5 & 50 & 1240 & 29,7 & 12 \\
\hline 6 & 60 & 1328 & 30 & 12 \\
\hline 7 & 70 & 1521 & 37,7 & 12 \\
\hline
\end{tabular}
telah dialirkan melalui rectifier (dioda bridge). Nilai tegangan DC mengalami penurunan setelah di searahkan dari teganan AC karena ada kerugian ketika dikonversi dari AC menjadi DC ketika berada didalam penyearah tersebut.

Tabel 2. Perubahan Kecepatan Rotasi Pada Rotor Setelah Dipasang Accu

Percobaan kedua yaitu pengukuran output tegangan dan arus pada saat setalah dipasang accu atau batrai dengan tegangan 12 Volt pada perubahan kecepatan rotasi rotor.

Keluaran VDC adalah tegangan keluaran searah sebab sudah disearahkan oleh rectifier (dioda 
penyearah). Karena telah dipasang accu maka arus sudah mengalir ke accu

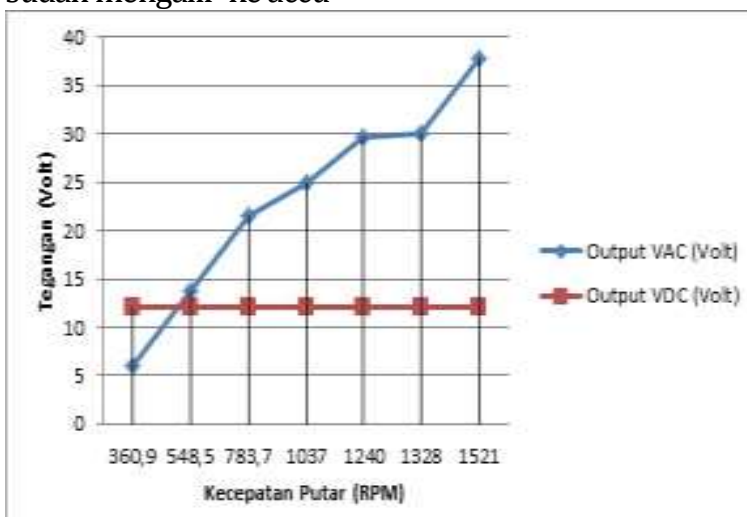

Gambar 2. Perubahan Kecepatan Rotasi Pada Rotor Setelah Dipasang Accu

Pada grafik diatas menunjukkan bahwa pada saat kecepatan putar rotor 367,9 RPM maka tegangan AC dikeluarkan sebesar 6 Volt. Pada saat kecepatan putar rotor 548,5 RPM maka tegangan AC yang dikeluarkan sebesar 13.9 Volt. Pada saat kecepatan putar rotor 783,7 RPM maka tegangan AC yang dikeluarkan sebesar 21,5 Volt. Pada saat kecepatan putar rotor 1037 RPM maka tegangan AC yang dikeluarkan sebesar 24,9 Volt. Pada saat kecepatan putar rotor 1240 RPM maka tegangan AC yang dikeluarkan sebesar 29,7 Volt. Pada saat kecepatan rotor 1328 maka tegangan AC yang dikeluarkan sebesar 30 Volt. Pada saat kecepatan putar rotor 1521 RPM maka tegangan yang dikeluarkan sebesar 37 Volt. Semakin tinggi kecepatan rotasi rotor (RPM) semakin tinggi pula keluaran tegangan AC-nya. Tegangan DC pada kecepatan rotasi rotor didapatkan hasil yang sama sebab itu merupakan tegangan awal pengukuran accu yaitu 12 Volt.

Percobaan pengecasan pada akumulator atau batrai dengan kapasitas awal batrai sebesar $56 \%$ dengan tagangan sebesar 11,1 Volt. Untuk kecepatan 10, 20, 30, KM/JAM tegangan DC yang dihasilkan oleh generator di bawah tegangan akumulator maka peneliti hanya mengambil sampel hanya pada kecepatan $30 \mathrm{KM} / \mathrm{JAM}$.

Tabel 3. Data Pengecasan Dalam Selang Waktu 15 Dan 30 Menit

\begin{tabular}{|c|c|c|c|c|c|c|c|}
\hline \multirow{2}{*}{ No } & \multirow{2}{*}{$\begin{array}{c}\text { Kecepatan } \\
\text { Kendaraan } \\
(\text { Km/Jam) }\end{array}$} & $\begin{array}{c}\text { Persentase } \\
\text { Batrai (\%) }\end{array}$ & $\begin{array}{c}\text { Tegangan } \\
(\mathrm{V})\end{array}$ & $\begin{array}{c}\text { Arus } \\
(\mathrm{A})\end{array}$ & $\begin{array}{c}\text { Persentase } \\
\text { Batrai (\%) }\end{array}$ & $\begin{array}{c}\text { Tegangan } \\
(\mathrm{V})\end{array}$ & $\begin{array}{c}\text { Arus } \\
(\mathrm{A})\end{array}$ \\
\hline 1 & 30 & 56 & 11,1 & 0 & 56 & 11,1 & 0 \\
\hline 2 & 40 & 60 & 11,16 & 0,09 & 65 & 11,26 & 0,09 \\
\hline 3 & 50 & 62 & 11,22 & 0,35 & 66 & 11,28 & 0,28 \\
\hline 4 & 60 & 64 & 11,24 & 0,59 & 67 & 11,29 & 0,56 \\
\hline 5 & 70 & 67 & 11,29 & 0,87 & 70 & 11,39 & 0,81 \\
\hline
\end{tabular}

Tabel 4. Data Pengecasan Dalam Selang Waktu 45 Dan 60 Menit

\begin{tabular}{|c|c|c|c|c|c|c|c|}
\hline \multirow{2}{*}{ No } & \multirow{2}{*}{$\begin{array}{c}\text { Kecepatan } \\
\text { Kendaraan } \\
(\mathrm{Km} / J a m)\end{array}$} & $\begin{array}{c}\text { Persentase } \\
\text { Batrai (\%) }\end{array}$ & $\begin{array}{c}\text { Tegangan } \\
(\mathrm{V})\end{array}$ & $\begin{array}{c}\text { Arus } \\
(\mathrm{A})\end{array}$ & $\begin{array}{c}\text { Persentase } \\
\text { Batrai (\%) }\end{array}$ & $\begin{array}{c}\text { Tegangan } \\
(\mathrm{V})\end{array}$ & $\begin{array}{c}\text { Arus } \\
(\mathrm{A})\end{array}$ \\
\hline 1 & 30 & 56 & 11,1 & 0 & 56 & 11,1 & 0 \\
\hline 2 & 40 & 67 & 11,29 & 0,09 & 68 & 11,33 & 0,05 \\
\hline 3 & 50 & 68 & 11,34 & 0,26 & 71 & 11,39 & 0,29 \\
\hline 4 & 60 & 69 & 11,38 & 0,57 & 72 & 11,42 & 0,57 \\
\hline 5 & 70 & 73 & 11,48 & 0,87 & 75 & 11,52 & 0,87 \\
\hline
\end{tabular}

Tabel 4.5. Data Pengecasan Dalam Selang Waktu 75 Menit

\begin{tabular}{|c|c|c|c|c|}
\hline \multirow{2}{*}{ No } & \multirow{2}{*}{$\begin{array}{c}\text { Kecepatan } \\
\text { Kendaraan } \\
(\text { Km/Jam) }\end{array}$} & $\begin{array}{c}\text { Persentase } \\
\text { Batrai (\%) }\end{array}$ & $\begin{array}{c}\text { Tegangan } \\
(\mathrm{V})\end{array}$ & $\begin{array}{c}\text { Arus } \\
(\mathrm{A})\end{array}$ \\
\hline 1 & 30 & 56 & 11,1 & 0 \\
\hline 2 & 40 & 67 & 11,29 & 0,09 \\
\hline 3 & 50 & 68 & 11,34 & 0,26 \\
\hline 4 & 60 & 69 & 11,38 & 0,57 \\
\hline 5 & 70 & 73 & 11,48 & 0,87 \\
\hline
\end{tabular}




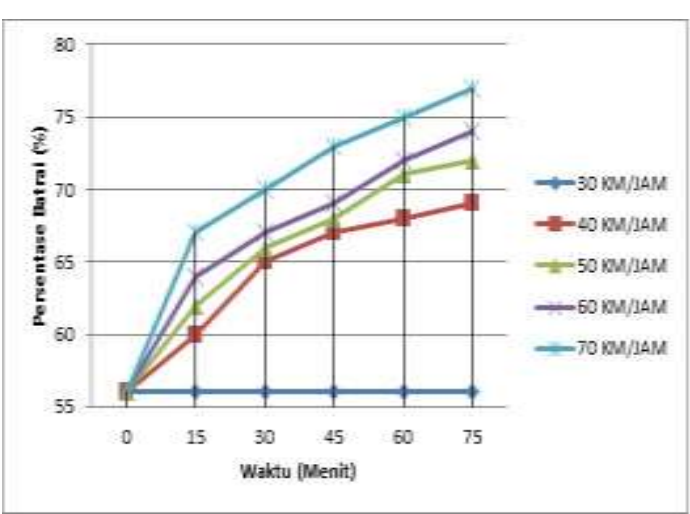

Gambar 3. Grafik Presentase Batrai Pengisian Selama 75 Menit

Grafik 3. adalah grafik presentase batrai untuk pengecasan dengan selang waktu 15,30,45,60,75 menit dengan start pengecasan pada presentase batrai 56\%. Pada saat kecepatan kendraan 40 $\mathrm{km} /$ jam presentase batrai yang didapat selama 15 menit adalah $60 \%$, untuk waktu 30 menit adalah $65 \%$, untuk waktu 45 menit adalah $67 \%$, untuk waktu 60 menit adalah 68\%, untuk waktu 75 menit 69\%. Pada saat kecepatan kendaraan $50 \mathrm{~km} / \mathrm{jam}$ presentase batrai yang didapat selama 15 menit adalah 62\%,untuk waktu 30 menit adalah 66\%, untuk waktu 45 menit adalah $68 \%$, untuk waktu 60 menit adalah $71 \%$, untuk waktu 75 menit $72 \%$. Pada saat kecepatan kendaraan $60 \mathrm{~km} / \mathrm{jam}$ presentase batrai yang didapat selama 15 menit adalah $64 \%$,untuk waktu 30 menit adalah 67\%, untuk waktu 45 menit adalah $69 \%$, untuk waktu 60 menit adalah $72 \%$, untuk waktu 75 menit $74 \%$. Pada saat kecepatan kendaraan $\mathrm{km} / \mathrm{jam}$ presentase batrai yang didapat selama 15 menit adalah 67\%,untuk waktu 30 menit adalah 70\%, untuk waktu 45 menit adalah $73 \%$, untuk waktu 60 menit adalah 75\%, untuk waktu 75 menit 77\%. Pada kecepatan 30 $\mathrm{km} /$ jam maka presentase batrai yang keluar adalah presentase awal pengisian yaitu 56\% karena arus belum keluar.

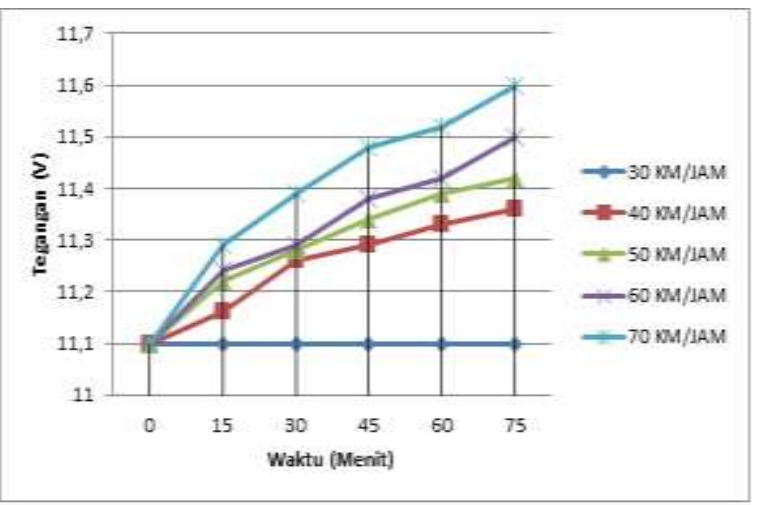

Gambar 4. Grafik Tegangan Batrai Pengisian Selama 75 Menit

Grafik 4. adalah grafik tegangan (v) batrai untuk pengecasan dengan selang waktu 15,30,45,60,75 menit dengan start pengecasan pada tegangan 11,1 volt. Pada saat kecepatan kendraan $40 \mathrm{~km} / \mathrm{jam}$ teganan yang dihasikan selama 15 menit adalah 11,16 volt, untuk waktu 30 menit adalah 11,26 volt, untuk waktu 45 menit adalah 11,29 volt, untuk waktu 60 menit adalah 11,33 volt, untuk waktu 75 menit 11,36 volt. Pada saat kecepatan kendraan 50 $\mathrm{km} /$ jam teganan yang dihasikan selama 15 menit adalah11,16 volt, untuk waktu 30 menit adalah 11,28 volt, untuk waktu 45 menit adalah 11,33 volt, untuk waktu 60 menit adalah 1,37 volt, untuk waktu 75 menit 11,4 volt.pada saat kecepatan kendraan 60 $\mathrm{km} / \mathrm{jam}$ teganan yang dihasikan selama 15 menit adalah 11,19 volt, untuk waktu 30 menit adalah 11,30 volt, untuk waktu 45 menit adalah 11,35 volt, untuk waktu 60 menit adalah 11,39 volt, untuk waktu 75 menit 11,40volt.pada saat kecepatan kendraan $70 \mathrm{~km} / \mathrm{jam}$ teganan yang dihasikan selama 15 menit adalah 11,30 volt, untuk waktu 30 menit adalah 11,38 volt, untuk waktu 45 menit adalah 11,50 volt, untuk waktu 60 menit adalah 11,56 volt, untuk waktu 75 menit 11,69 volt. Pada kecepatan $30 \mathrm{~km} / \mathrm{jam}$ maka tegangan yang keluar adalah tegangan awal pengisian yaitu 11,1 volt karena tegangan batrai belum naik.

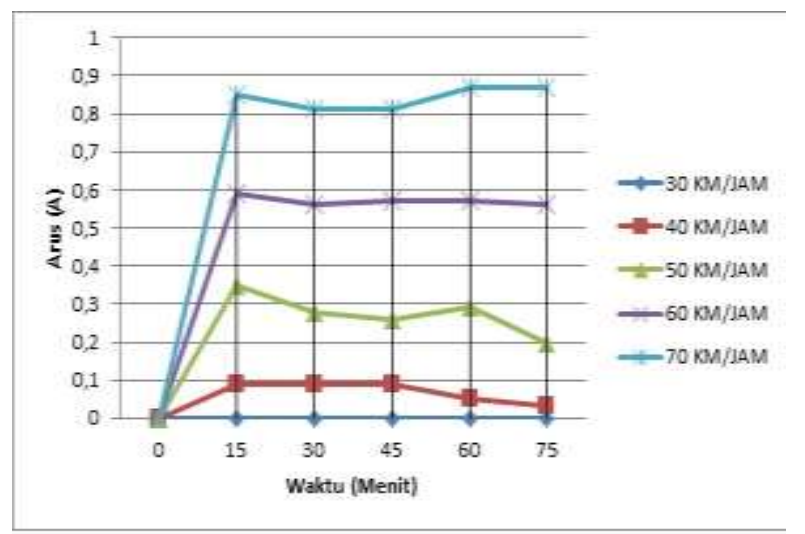

Gambar 5. Grafik Arus Pengisian Batrai Selama 75 Menit

Grafik 5. adalah grafik arus (ampere) batrai untuk pengecasan dengan selang waktu 15,30,45,60,75 menit. Pada saat kecepatan kendraan $30 \mathrm{~km} / \mathrm{jam}$ tidak ada arus yang mengalir ke batrai karena tegangan yang dihasilkan oleh generator kurang dari 12 volt pada saat kecepatan kendaraan 40 $\mathrm{km} / \mathrm{jam}$ maka arus yang didapat pada 15 menit sebesar 0,09 ampere, pada saat kecepatan kendaraan $40 \mathrm{~km} / \mathrm{jam}$ maka arus yang didapat pada 30 menit sebesar 0,09 ampere, pada saat kecepatan kendaraan $40 \mathrm{~km} / \mathrm{jam}$ maka arus yang didapat pada 45 menit sebesar 0,09 ampere, pada saat kecepatan kendaraan $40 \mathrm{~km} / \mathrm{jam}$ maka arus yang didapat pada 60 menit sebesar 0,05 ampere, pada saat kecepatan kendaraan $40 \mathrm{~km} / \mathrm{jam}$ maka arus yang didapat pada 75 menit sebesar 0,03 ampere. Pada saat kecepatan kendaraan $50 \mathrm{~km} / \mathrm{jam}$ 
maka arus yang didapat pada 15 menit sebesar 0,35 ampere, pada saat kecepatan kendaraan $50 \mathrm{~km} / \mathrm{jam}$ maka arus yang didapat pada 30 menit sebesar 0,28 ampere, pada saat kecepatan kendaraan $50 \mathrm{~km} / \mathrm{jam}$ maka arus yang didapat pada 45 menit sebesar 0,26 ampere, pada saat kecepatan kendaraan $50 \mathrm{~km} / \mathrm{jam}$ maka arus yang didapat pada 60 menit sebesar 0,29 ampere, pada saat kecepatan kendaraan $50 \mathrm{~km} / \mathrm{jam}$ maka arus yang didapat pada 75 menit sebesar 0,20 ampere. Pada saat kecepatan kendaraan $60 \mathrm{~km} / \mathrm{jam}$ maka arus yang didapat pada 15 menit sebesar 0,59 ampere, pada saat kecepatan kendaraan $60 \mathrm{~km} / \mathrm{jam}$ maka arus yang didapat pada 30 menit sebesar 0,56 ampere, pada saat kecepatan kendaraan $60 \mathrm{~km} / \mathrm{jam}$ maka arus yang didapat pada 45 menit sebesar 0,57 ampere, pada saat kecepatan kendaraan $60 \mathrm{~km} / \mathrm{jam}$ maka arus yang didapat pada 60 menit sebesar 0,57 ampere, pada saat kecepatan kendaraan $60 \mathrm{~km} / \mathrm{jam}$ maka arus yang didapat pada 75 menit sebesar 0,56 ampere. Pada saat kecepatan kendaraan $70 \mathrm{~km} / \mathrm{jam}$ maka arus yang didapat pada 15 menit sebesar 0,87 ampere, pada saat kecepatan kendaraan $70 \mathrm{~km} / \mathrm{jam}$ maka arus yang didapat pada 30 menit sebesar 0,81 ampere, pada saat kecepatan kendaraan $70 \mathrm{~km} / \mathrm{jam}$ maka arus yang didapat pada 45 menit sebesar 0,87 ampere, pada saat kecepatan kendaraan $70 \mathrm{~km} / \mathrm{jam}$ maka arus yang didapat pada 60 menit sebesar 0,87 ampere, pada saat kecepatan kendaraan $70 \mathrm{~km} / \mathrm{jam}$ maka arus yang didapat pada 75 menit sebesar 0,85 ampere.

\section{PENUTUP}

Dari hasil penelitian ini dapat disimpulkan bahwa maksumum daya rata-rata yang dapat dihasilkan adalah 9,903 watt hasil tersebut merupakan pengujian dengan kecepatan konstan 70 km/jam selama 75 menit sehingga lamanya perkiraan waktu pengecasan derdasarkan data tersebut adalah 5,576 jam. Saran yang dapat diberikan untuk mengembangkan alat ini adalah yang pertama diperlukannya peningkatan pada generator yang dipakai yang kedua diperlukannya bahan yang dapat menahan air agar alat ini mampu dipakai dalam kaondisi hujan sekalipun.

\section{DAFTAR PUSTAKA}

Abdan Syakuro. (2014). Makalah Energi Listrik Pengertian Konduktor, Isolator ,Dan Semi Konduktor Listrik.

Afifah, Y. N. (2016). ALIRAN TAK TUNAK FLUIDA NANO MAGNETOHIDRODINAMIK ( MHD ) YANG MELEWATI BOLA.

Afifah, Y. N. (2019). (2019). Analysis of Unsteady Magneto Hydro Dynamic ( MHD ) Nano Fluid Flow Past A Sliced Sphere Analysis of Unsteady Magneto Hydro Dynamic ( MHD ) Nano Fluid Flow Past A Sliced Sphere. IOP Conference Series: Materials Science and
Engineering, 494,

https://doi.org/10.1088/1757-

899X/494/1/012033

Afifah, Y. N., \& Putra, B. C. (2018). Model Matematika Aliran Tak Tunak Pada Nano Fluid Melewati Bola Teriris Dengan Pengaruh Medan Magnet. Teknika: Engineering and Sains Journal, 2(2), 119-124.

Amin, M. Al, \& Asnawi, R. (2017). Sepeda Statis Sebagai Pembangkit Energi Listrik. 1(2), 119128.

Gunawan, E. et al. (2019) 'Analysis of the Effect of Current Flow Variations in GTAW on SS 400 Plate Material Connected with SUS 304 Stainless Steel Plate Against Tensile Strength and Hardness with ER308L Electrodes', Journal of Physics: Conference Series, 1175(1). doi: 10.1088/1742-6596/1175/1/012277.

Muhamad Wahyu Santoso. (2015). Makalah generator.

Muhammad Maulana Rafasandi. (2018). Perancangan Mini Pembangkit Listrik Tenaga Angin Pada Sepeda Motor. (April). https://doi.org/.1037//0033-2909.126.1.78

Prasetijo, H., Ropiudin, \& Dharmawan, B. (2012). Generator Magnet Permanen Sebagai Pembangkit Listrik Putaran Rendah. Jurnal Dinamika Rekayasa.

Prasetyo, A. E., Purnamasari, D., Ali, M., \& Ririn. (2014). TUGAS ELEKTROKIMIA MAKALAH BATERAI DAN FUEL CELL.

Sakura, A. (2017). Rancang Bangun Generator Sebagai Sumber Energi Listrik Nanohidro. Universitas Lampung.

Setiawan, A. (2009). Disain Pembangkit Listrik Tenaga Pedal Sebagai Sumber Energi Alternatif di Daerah Pedesaan.

Sunandar, R., Elektro, J. T., Teknik, F., \& Surakarta, U. M. (2015). Pemanfaatan Sepeda Statis Sebagai Sumber Energi Alternatif Menggunakan Sepul Sepeda Motor. Retrieved from file:///F:/refrensi/skripsi/PEMANFAATAN SEPEDA STATIS SEBAGAI SUMBER ENERGI ALTERNATIF MENGGUNAKAN SEPUL SEPEDA MOTOR.pdf\%0D

Putra, B. C., \& Afifah, Y. N. (2018). Gaussian Mixture Model Untuk Penghitungan Tingkat. Teknika: Engineering and Sains Journal, 2, 53-58.

Yunita Nur Afifah, MNH Qomarudin, \& Imamatul Ummah. (2020). Optimal Control Model Pemanenan Prey-Predator di Area Konservasi Ikan. Buana Matematika: Jurnal Ilmiah Matematika Dan Pendidikan Matematika, 10(1), 1-16. https://doi.org/10.36456/buanamatematika. v10i1.2410 
I Umarella / Mechonversio, Vol. 2, No.1, Juni 2019, 1 - 8

Halaman ini sengaja dikosongkan 